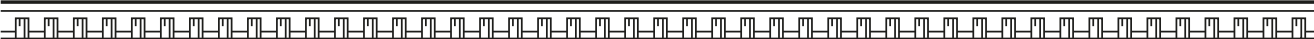

Vestnik drevney istorii

81/2 (2021), 662-675

(C) The Author(s) 2021
Вестник древней истории

81/2 (2021), 662-675

(с) Автор(ы) 2021

DOI: $10.31857 / \mathrm{S} 032103910015608-1$

\title{
OEDIPUS’ EDICT AND CURSE
}

\author{
Sophocles' Oedipus Tyrannus, 236-243
}

\author{
Boris M. Nikolsky \\ Russian Presidential Academy of National Economy and Public Administration, Moscow, Russia; \\ A.M. Gorky Institute of World Literature, Russian Academy of Sciences, Moscow, Russia; \\ National Research University Higher School of Economics, Moscow, Russia \\ E-mail: borisnikolsky@gmail.com
}

The article deals with the problem of the addressee of Oedipus' curse in Sophocles' Oedipus Tyrannus 236-243. It is suggested that the curse is directed both against the murderer of Laius and against all potential informants who are concealing the murderer's name. The ambivalence, or rather the incongruity, of Sophocles' text is explained by the double rhetorical aim of Oedipus' monologue: it is at once an edict demanding to reveal the identity of the murderer and a curse against the murderer himself. The double rhetorical function of the monologue derives from its double dramatic role. On the one hand, it begins the action of the play, which consists in revealing the murderer's identity, and on the other hand, the curse acts as the play's leitmotif: it is cited throughout the tragedy and determines Oedipus' future fate.

Keywords: tragedy, Sophocles, Oedipus, edict, curse, murderer

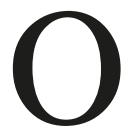
edipus' monologue opening the first episode of Sophocles' Oedipus Tyrannus is crucial both for the development of the plot and for the thematic organization of the play. Oedipus declares here an edict requiring the Thebans to find and extradite the murderer, the edict which Oedipus himself will be destined to execute, and here he pronounces a curse which will eventually be turned against himself. At the same time, the monologue poses many problems related to textual criticism and to the interpretation of the text. We will attempt to resolve one of such issues in this article.

Author. Boris M. Nikolsky - Dr. Hab. (Philology), Head of the Department of Ancient Literature, A.M. Gorky Institute of World Literature of the Russian Academy of Sciences; Senior Research Fellow at The School for Advanced Studies in Humanities, Russian Presidential Academy of National Economy and Public Administration (RANEPA); Professor at National Research University Higher School of Economics.

This article is a translation of: Никольский Б.М. Указ и проклятие Эдипа (Софокл «Царь Эдип» ст. 236-243). Journal of Ancient History [Vestnik drevney istorii] 81/2 (2021), 81/2 (2021), 316-330. DOI: $10.31857 / \mathrm{S} 032103910014828-3$.

The paper is prepared with the finantial support of the Russian Foundation for Basic Research (project no. 20-59-14002 АНФ_a). 
When Oedipus proclaims his edict, he demands from the citizens of Thebes if any of them knows the murderer of Laius to share this knowledge with him (vv. 224-226):

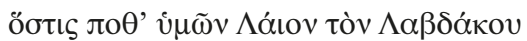

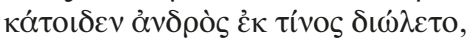

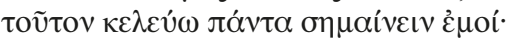

Whoever among you knows at whose hands

Laius, son of Labdacus, perished,

him I command to tell me all! ${ }^{1}$

Oedipus promises a reward to anyone who gives up the murderer; and if the murderer confesses himself guilty he will be released from punishment and will only have to leave the country (vv. 227-232):

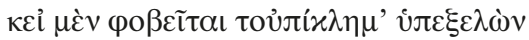

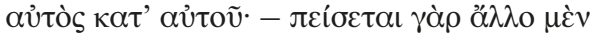

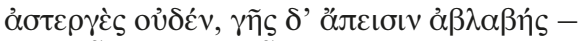

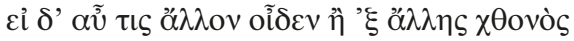

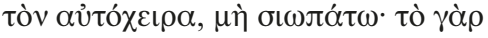

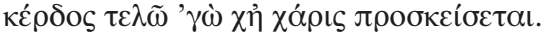

If he is afraid taking out an accusation

against himself: he shall suffer nothing else unwelcome,

but shall leave the land unharmed.

But if someone knows another of you,

or a foreigner, to be the killer, let him not be silent;

for I can dispense rewards, and gratitude also shall be his.

Then Oedipus announces what his actions will be if the Thebans remain silent and harbour the murderer (vv. 233-243):

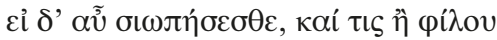

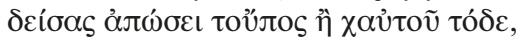

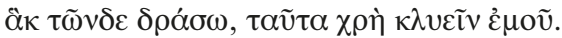

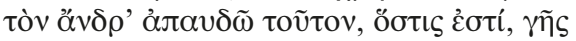

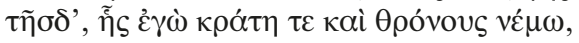

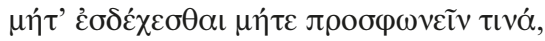

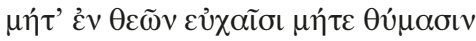

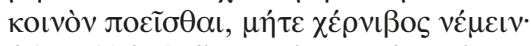

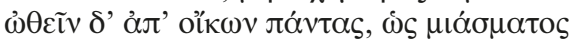

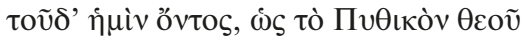

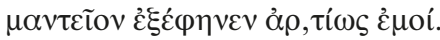

But if you remain silent, and someone, fearing for a friend or for himself, rejects this orderwhat I shall do then you must hear from me!

I forbid all belonging to this land, over which I rule and sit upon the throne, to receive him or to speak to him, or to let him share in prayers and sacrifices to the gods, or to touch holy water; but all must drive him from their homes, since we are polluted, as the Pythian oracle of the god has just now revealed to me.

${ }^{1}$ Here and elsewhere in this article the translation of Sophocles' plays by Lloyd-Jones is used (with some alterations). 
He explains this edict by his ardent desire to fulfil Apollo's oracle demanding that the murderer of Laius be found and his willingness to help the deceased king (vv. 244-245):

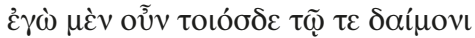

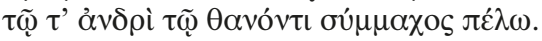

This is how I shall fight side by side with the god and with the man who died.

Oedipus concludes his edict with two additional curses - one directed against the murderer and the other against himself if he deliberately conceals the murderer in his own house (vv. 246-251):

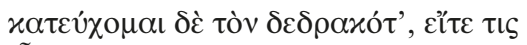

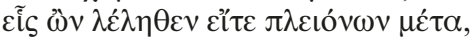

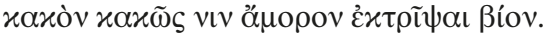

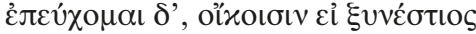

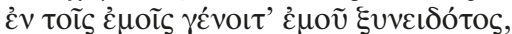

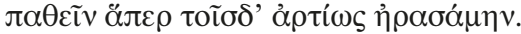

And I pray that the doer of the deed,

whether a single man has gone undetected or he has acted with others,

may wear away a miserable life in misery, miserable as he is.

And I pray further that if he is by the hearth

in my own house with my own knowledge,

I may suffer the fate with which I have just cursed others.

The interpretation of this text is highly controversial. One of the main questions for

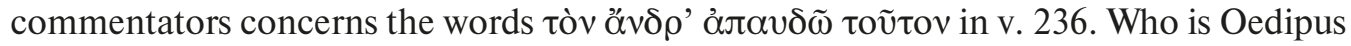
referring to here?

Most scholars ${ }^{2}$ believe that the order to exclude "this man" from social life in the city should refer to the murderer. There are compelling reasons for this point of view.

First, in vv. 241-243 Oedipus indicates the reason why "this man" should be denied communication and participation in shared sacrifices: he is the bearer of $\mu i \alpha \sigma \mu \alpha$, as the oracle revealed. We know that the oracle in calling for the expulsion of $\mu$ í $\alpha \sigma \mu \alpha$ was referring specifically to the murderer of Laius. Creon, conveying the command of the

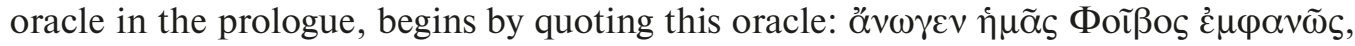

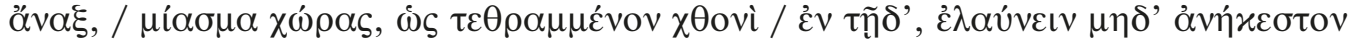
$\tau \rho \varepsilon ́ \varphi \varepsilon ı v$ "The lord Phoebus orders us plainly / to drive out from the land a pollution, one that has been nourished in this country, / and not to nourish it till it cannot be cured" (vv. 96-98). Then he explains that the bearer of the filth is the murderer:

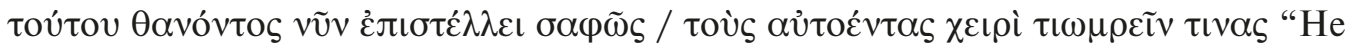
was killed, and the god now tells us plainly to punish his killers, whoever they may be" (vv. 106-107).

Second, the words of Oedipus' command are repeated several times further on in the tragedy, and the characters when recalling them always refer to the murderer. Initially he is addressed by Tiresias. Annoyed by the anger of Oedipus who does not understand why the soothsayer conceals the name of the murderer from him Tiresias says (vv. 350-353):

${ }^{2}$ Blaydes 1859, 49, comm. to v. 242; Schneidewin 1856, 54, comm. to vv. 236-237; Ribbeck 1858; Ribbeck 1861; Jebb 1914, 43 (trans.: 'the slayer'); Lloyd-Jones, Wilson 1990, 86; Finglass 2018, 247-249, comm. to vv. 236-240. 


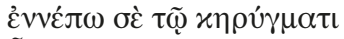

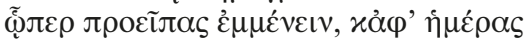

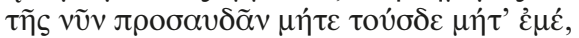

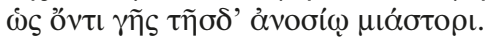

I call on you to abide by the proclamation

you made earlier, and from this day on

address neither these men nor me,

since you are the unholy polluter of this land!

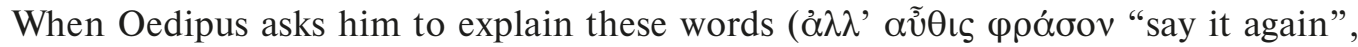

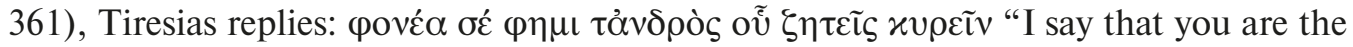
murderer of the man whose murderer you are searching for" (362).

Then Oedipus himself begins to guess that the stranger he killed may have been Laius, and recalls his own curse in dread (vv. 815-820):

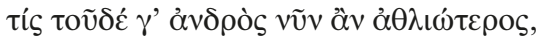

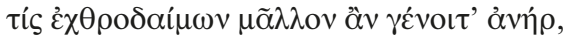

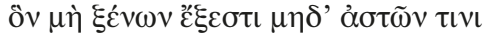

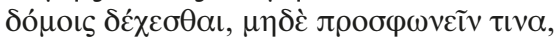

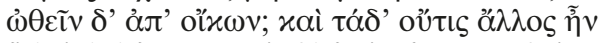

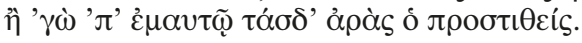

who now could be more miserable,

and who more hateful to the gods, than I,

whom no stranger and no citizen may receive in his home,

whom no man may address,

but all must drive from their houses. And it was none other

than I myself who laid upon myself these curses.

Finally, Oedipus recalls the curse again at the end of the play when he learns a terrible secret about himself and is finally convinced that his curse is turned against himself. He wishes to flee the country and not stay in his house any longer, for he falls under the

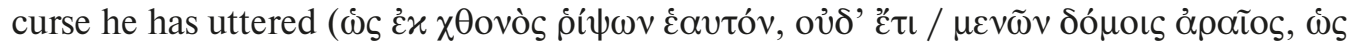

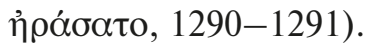

On the other hand, some commentators attribute this command of Oedipus not to the murderer but to those Thebans who will conceal the name of the murderer ${ }^{3}$. This interpretation can also be justified by quite strong arguments.

First, this meaning follows from the logical development of Oedipus' speech. Initially, Oedipus promises a reward to the one who will not remain silent and reveal the identity of the murderer (vv. 227-232). The next part, which begins with the words عi $\delta$ ' $\alpha \tilde{v}$

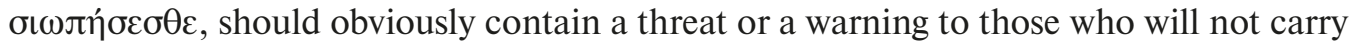
out the edict and will not betray the murderer.

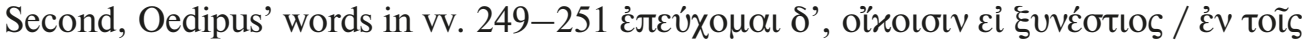

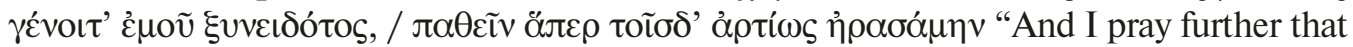
if he is by the hearth / in my own house with my own knowledge, / I may suffer the fate with which I have just cursed others", expressing the hero's readiness to take the curse upon himself if he harbours the murderer in his house, are understandable only if he has previously ut-

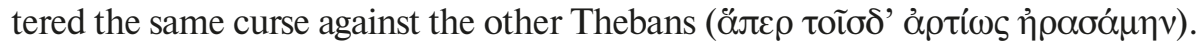

Third, only if Oedipus' curse is directed against those who know the murderer and do not denounce him, we can explain the response of the chorus to his monologue

${ }^{3}$ Classen 1861; Knox 1957, 81-82; 1959; Carawan 1999. 


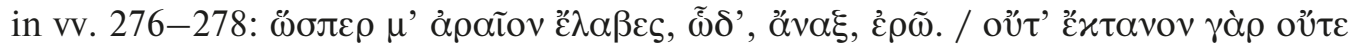

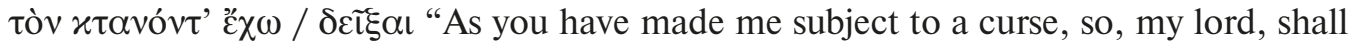
I speak. / I did not kill him, neither can I point to / the killer". Commentators usually assume that the chorus, by calling itself ó oxĩo "subject to a curse", refers to the final words of Oedipus' monologue, where the hero appeals to the gods to continue send-

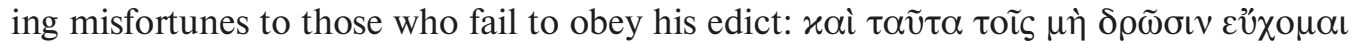

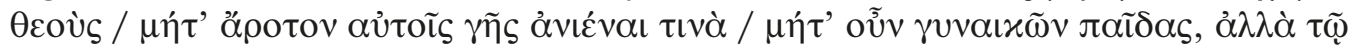

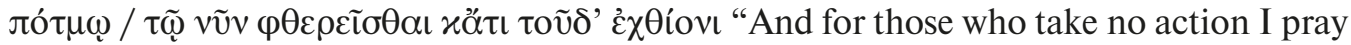
that the gods / may not send up crops from the earth / nor allow their women to bear children, but that they may perish / by the fate that now afflicts them or by one yet worse"

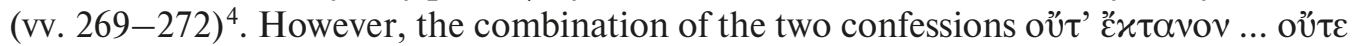

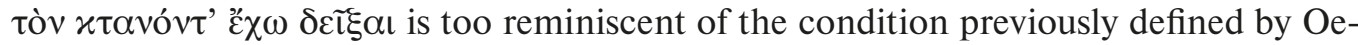

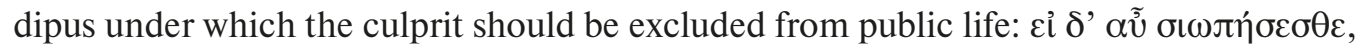

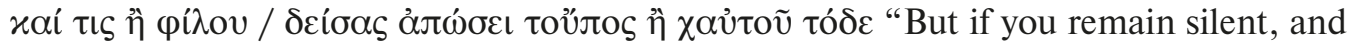
someone, fearing for a friend or for himself, rejects this order" (vv. 233-234). Further-

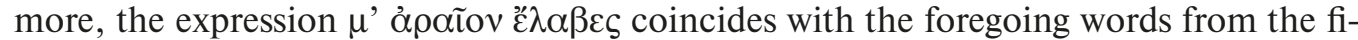
nale of the tragedy, where Oedipus himself turns out to be "subject to the curse": $\alpha \rho \alpha \tilde{t o s}$,

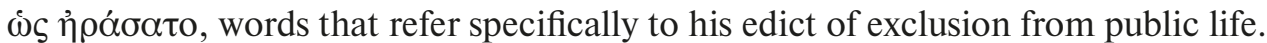

Finally, it is only with this interpretation of the curse that the exchange of remarks between Oedipus and the chorus following Oedipus' monologue (vv. 292-296) is understandable. The hero here expresses regret that, although everyone has heard that Laius was killed by some strangers, no one has seen the murderer ( 293). The chorus suggests, however, that if the murderer is familiar with fear, he will not

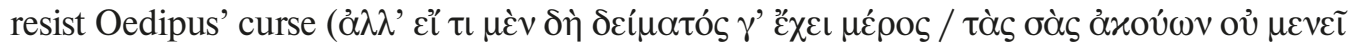

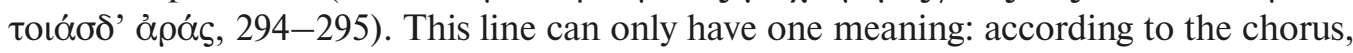
the murderer will certainly tell about his deed and then free himself from the curse ${ }^{5}$. Hence, the chorus considers the curse to be valid only if the murderer is hiding; it is the concealment of the secret, not the murder itself, that is the basis for the present punishment.

Thus, as we may see, Oedipus' claim in vv. 236-243 can be understood in two ways, and each interpretation has a convincing evidence. Each commentator chooses one of these two interpretations and rejects the other, and that always leads to an artificial or simply wrong understanding of the words of the edict itself as well as other related passages. Let us first take a look at the mistakes made by those scholars who attribute the curse to the Thebans harbouring the murderer, while denying that it can refer to the murderer himself.

We shall begin with the text of this command. As I noted above, Oedipus demands that "this man" be excommunicated, referring to the oracle, which indicated the existence of $\mu$ ía $\mu \alpha$ in the city (vv. 241-243):

${ }^{4}$ See Finglass 2018, 261, comm. to vv. 276-278.

${ }^{5}$ Finglass understands this passage in a different way. He believes that, according to the chorus, the murderer, in fear of Oedipus' curse, must flee. However, it is unlikely that the murderer's secret escape could be seen as fulfilling Apollo's will and would satisfy Oedipus. In support of his point of

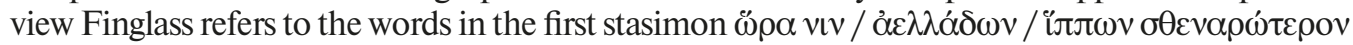

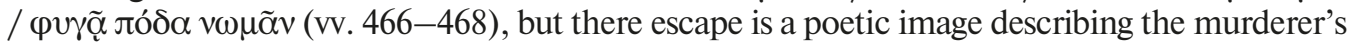
departure into exile. 
...ஸ́s $\mu \mathrm{i} \sigma \alpha \mu \alpha \tau o \varsigma$

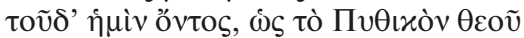

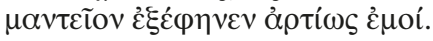

since we are polluted,

as the Pythian oracle of the god

has just now revealed to me.

It would be reasonable to associate $\mu i \alpha \sigma \mu \alpha$ precisely with the murderer and to understand the participle clause with $\omega \varsigma$ as causal, just as it is used further when Tiresias re-

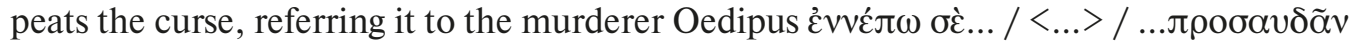

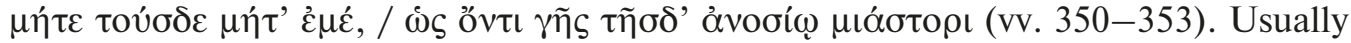

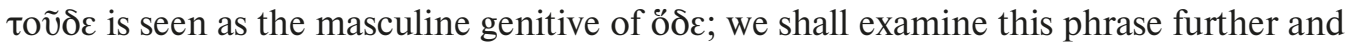
offer a slightly different interpretation, but in any case it is obvious, that it is the murderer who is the chief bearer of $\mu i \alpha \sigma \mu \alpha$, and it is the murderer to whom the oracle men-

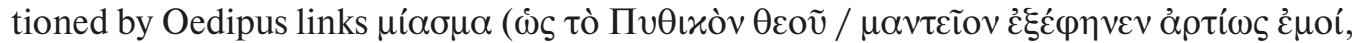
242-243). Knox in his translation ${ }^{6}$, when referring Oedipus' words not to the murderer but to the man who knows but conceals the truth, understands the first $\omega \varsigma$, introducing the participle, in a comparative rather than causal sense - "as if he were himself the source of infection". Carawan sees here an even stronger and a more direct statement; in his opinion, it is already clear to the audience that the one who has been initiated into the murder mystery is a carrier of filth, so the participle clause can also have a causal meaning ("all must drive him from their homes as a defiler of us all"). But in both cases the reference to the words of the oracle remains unclear - the oracle did not say that one should persecute someone who knows but is concealing a murderer or that this particular person is associated with the filth. Carawan leaves this inconsistency in his interpretation unexplained, and Knox simply smoothes it out in his translation. He suggests that the reference to Apollo explains only the word $\mu$ ío $\mu \alpha$ and not the entire preceding phrase ("as if he were himself the source of infection which Apollo's oracle has just made known to me"). In that case, however, the Greek text should read on and not ws.

Carawan tries to relate to the potential informant all the subsequent passages as well, which bring us back to this curse ${ }^{7}$. In his view, when Tiresias, in his anger, reveals the secret to Oedipus, stating that he himself must undergo the punishment he has determined

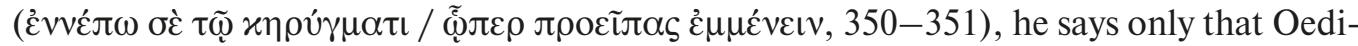
pus knows the murderer, but does not yet call him the murderer. But then what about the following statement by Tiresias, in which he clarifies the meaning of his enigmatic hint?

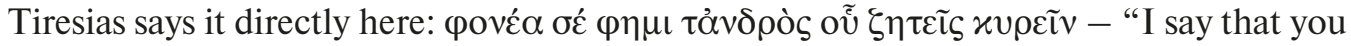
are the murderer of the man whose murderer you are searching for" (v. 362). According to Carawan pové $\alpha$ is not used in this phrase to mean "murderer/killer", but "guilty as the killer". Needless to say, such an interpretation is impossible and is only due to the scholar's desire to find the meaning he wants in the line. This same desire leads him to a highly dubious interpretation of two other passages in which Oedipus himself recalls the curse - first fearing that he might be the murderer (vv. 813-820) and then being convinced of it (vv. 1290-1291). In his view, Oedipus is referring here only to his "additional" curse, the one he has directed against himself in case of concealing the murderer

\footnotetext{
${ }^{6}$ Knox 1959.

${ }^{7}$ Carawan 1999, 213-217.
} 
in his house (vv. 249-251). It is difficult to dispute the fact that he does not accidentally utter this "additional" curse and that it also echoes at the end of the drama, but the main and most tragic echo here is certainly with his strongest and the most emotional command in vv. 236-243, and it arises because Oedipus turns out to be the murderer and not someone who knows but is hiding the truth.

On the other hand, those commentators who link vv. 236-243 exclusively with the murderer also have to rely on far-fetched interpretations to prove their point.

Let us first turn to the very command to exclude the culprit from communication and the context in which it is made. Oedipus first promises leniency or a reward to those who will tell about the crime. Then he begins to talk about what he is prepared to do if the Thebans keep quiet. Obviously his words should sound like a threat and the threat should be aimed at those who will disobey, i.e. those who will remain silent (vv. 233-235):

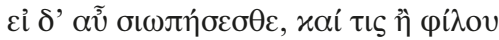

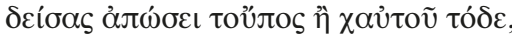

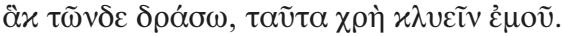

But if you remain silent, and someone, fearing for a friend or for himself, rejects this orderwhat I shall do then you must hear from me!

Commentators, for whom the subsequent curse is directed against the murderer, have to understand these three verses differently. Henry and after him Finglass explain them as follows ${ }^{8}$. In their view, Oedipus is not threatening but is willing to accept that the murderer will not be extradited. With his command to exclude the murderer from social life he only wants to reduce the risk of filth - he expects the Thebans to, if they are not ready to completely get rid of the filth, at least limit it by cutting off communication with the murderer. This is, by the way, how Shervinsky also understands the passage and translates it into Russian:

Но если даже вы и умолчите, За друга ли страшась иль за себя,-

Дальнейшую мою узнайте волю:

Приказываю, кто бы ни был он,

Убийца тот, в стране, где я у власти,

Под кров свой не вводить его и с ним

Не говорить ${ }^{9} . .$. ,

Not only does such an interpretation weaken the meaning of this claim, depriving it of the power of a terrible curse that can echo in crucial moments of the drama, it is also grammati-

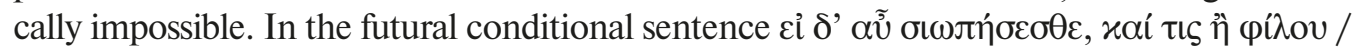

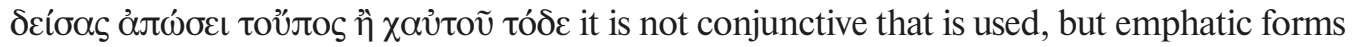
of the future tense which are supposed to express the meaning of admonition or threat. Thus Oedipus' command can only be a threat addressed to those who refuse to speak.

Those who attribute Oedipus' curse exclusively to the murderer point to the expression

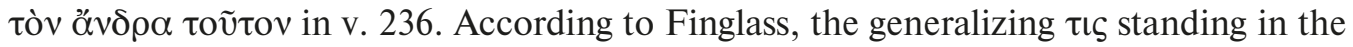

\footnotetext{
${ }^{8}$ Henry 1969, 126; Finglass 2018, 248.

${ }^{9}$ But even if you keep silent, / whether you fear for your friend or for yourselves. / Find out my further will: / I command you, whoever that murderer may be, / in the land where I am in power, / not to bring him under your roof, / nor speak to him...
} 
subordinate clause cannot be continued by this emphatic and a very particular phrase,

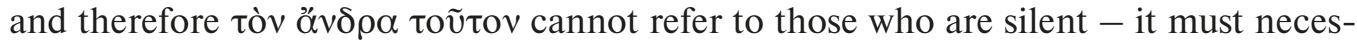
sarily refer to the murderer ${ }^{10}$. This argument, however, is flawed. We find a similar use of oṽ̃os ó ơvท́ $\rho$ in a general rather than specific sense, and also with a reference to the preceding sentence, e.g. in Antigone, vv. 666-671:

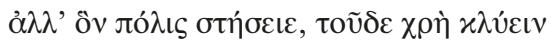

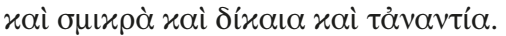

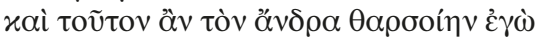

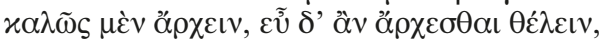

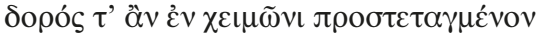

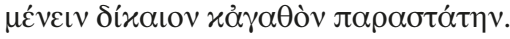

One must obey the man whom the city sets up in power

in small things and in justice and in its opposite.

This is the man whom I would trust

to be a good ruler and a good subject,

and when assigned his post in the storm of battle

to prove a true and noble comrade in the fight.

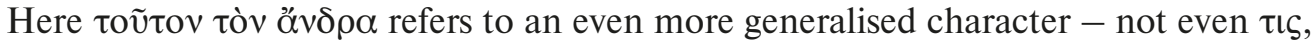
but the unexpressed and unspecified subject of the verb xגúcı. In another example,

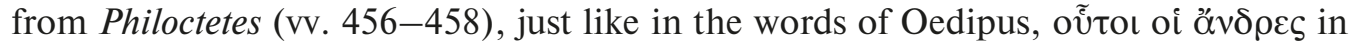
the main clause summarizes the previous subordinate clause that also has a generalizing meaning (it is introduced by ӧлоv "wherever"):

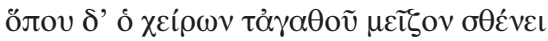

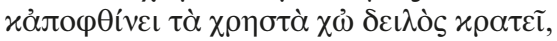

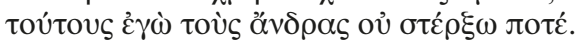

Where the worse man has more power than the better, what is good perishes, and the coward is in power,

the men in that place I will never tolerate.

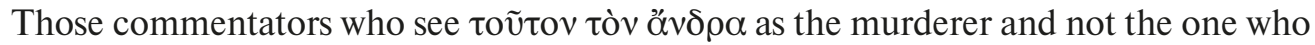
harbours him have to somehow manage the curse that Oedipus has turned against himself. Oedipus says (vv. 249-251):

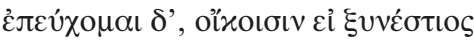

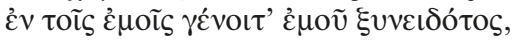

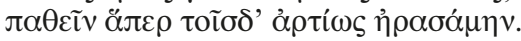

And I pray further that if he is by the hearth

in my own house with my own knowledge,

I may suffer the fate with which I have just cursed others.

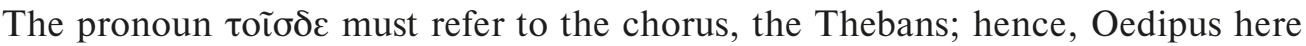
speaks of his readiness to take the punishment he had just threatened the citizens of Thebes with. Assuming that the command he had just made for excommunication applied to any citizen of Thebes who did not denounce the murderer, this new curse is under-

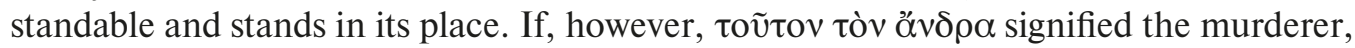

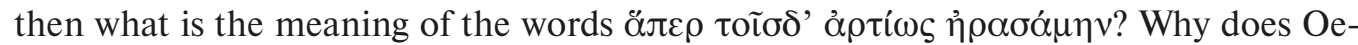
dipus use this demonstrative pronoun to indicate the present person, and also in plural?

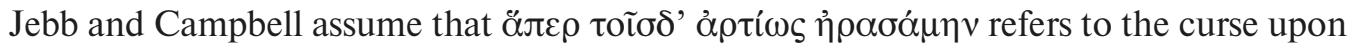

${ }^{10}$ Finglass 2018, 248. 


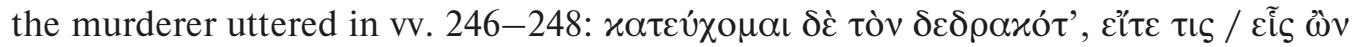

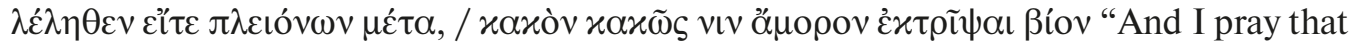
the doer of the deed, / whether a single man has gone undetected or he has acted with others, / may wear away a miserable life in misery, miserable as he is". They suggest that

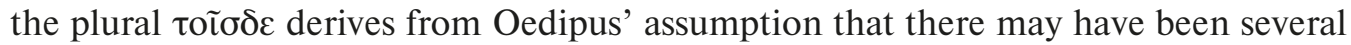

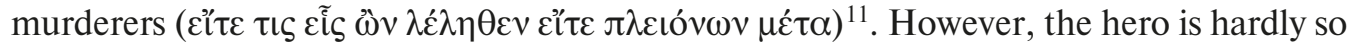
concerned with this assumption as to start speaking about murderers in plural; the phrase

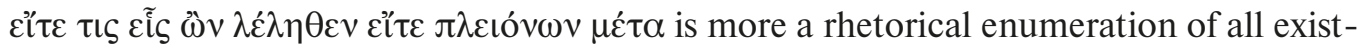
ing possibilities than an independent judgment. An even more obvious objection can be made by drawing attention to the adverb ó $\rho \tau i ́ \omega s$. According to Jebb and Campbell, it should refer back to the previous phrase. However, when ó $\rho \tau i \omega \varsigma$ refers to some words previously said in the text, it always brings us back to them - back after another conversation, another discourse, or another event. "As I have just said" always sounds like a reminder; this expression cannot follow immediately after the words spoken (cf. all examples from Sophocles: $\alpha \rho \tau i \omega \varsigma$ in Ajax 1321 brings us back to the previous scene ending at vv. 1315, in Electra 347 to vv. 333-334, 481 to 417-423, in Oedipus Tyrannus 243 and 474 to $96-98,726$ to 716,745 to the curse in vv. 236-237, 1054 to 859-860, in Trachiniae 346 to 248-290, in Philoctetes 764 to 656-657). Other commentators and publishers prefer to emend the text. Ribbeck moved these verses to the end of the monologue, inserting them after Oedipus' final curse upon all those who would not obey his edict (xai

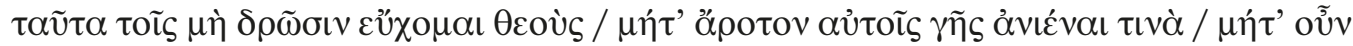

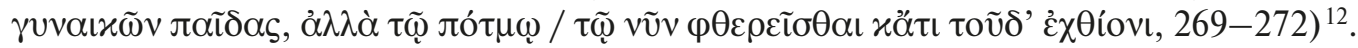
However, this generalising curse concludes the monologue perfectly, and the mentioning of Oedipus' particular case then disrupts the rhetorical ending; moreover, it intrudes inappropriately between this curse and an equally generalising wish for the welfare of all

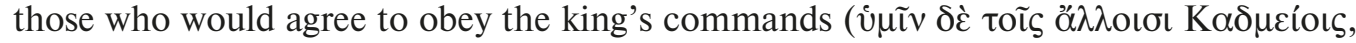

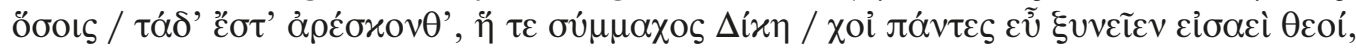
273-275). Finglass and Lloyd-Jones, following Wecklein, exclude vv. 249-251 from the text ${ }^{13}$; however, these verses contain, and perhaps even most strongly express, the tragic irony with which the entire Oedipus' monologue is filled - the irony that Oedipus is actually turning his words on himself.

The only conclusion that can be drawn from all what has been said above is that both interpretations of Oedipus' command to deny communication to the culprit are correct, it is directed both against the murderer and against those of the Thebans who would conceal the truth. His curse is ambiguous ${ }^{14}$, or rather inconsistent. In the context in which

11 Jebb 1914, 44, comm. to vv. 246 and 45, comm. to v. 251; Campbell 1879, 162, comm. to vv. 246-251.

12 Ribbeck 1858.

${ }^{13}$ Wecklein 1880; Finglass 2018, 251; Lloyd-Jones 1994.

${ }^{14}$ The double reference of the curse was suggested by Dyson, who sees here a deliberate authorial ambiguity (Dyson 1973, 205-206). According to him, an important fact, known to the audience but not yet understood by Oedipus, is the equivalence between the witness and the murderer, and the ambivalence of the curse should underline, for an informed audience, this equivalence. Dyson finds another example of the same identification in the conversation between Oedipus and the chorus that follows the monologue (vv. 292-296) already mentioned above. Here, 
these words are spoken, we expect a threat against the person who harbours the murderer, but the command itself should rather refer to the murderer; then, over the course of the drama, these words are given one meaning and then another.

Some suggestions can be made about the reasons for this inconsistency. It may be due to the fact that Sophocles, in constructing Oedipus' monologue, seeks to solve two dramatic problems simultaneously. First, the monologue begins the action of gradually solving the murder of Laius. Oedipus must issue an edict allowing him to begin the search for the murderer - the edict requiring the Thebans to name the murderer. The denouement of this storyline will be the moment of recognition, i.e. the discovery of the murderer. Second, here Sophocles forces Oedipus to pronounce a curse upon the murderer, which will also be crucial to the plot: the author will come back to it throughout the drama, and it will determine Oedipus' fate after the recognition. The author solves both of these problems by ironically emphasising Oedipus' lack of understanding of his situation. On the one hand, the hero demands to share information with him, not realising that he is in possession of it. On the other hand, he threatens to punish the murderer, not realising that he himself is the murderer.

These two compositional tasks also determine the monologue's two rhetorical functions - it is both an edict addressed to the Thebans and a curse upon the murderer. It begins as an edict, demanding that the murderer be exposed (vv. 224-226):

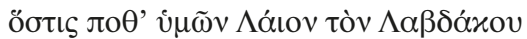

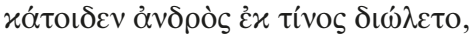

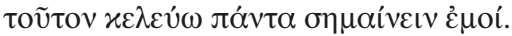

Whoever among you knows at whose hands

Laius, son of Labdacus, perished,

him I command to tell me all!

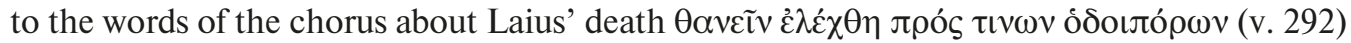

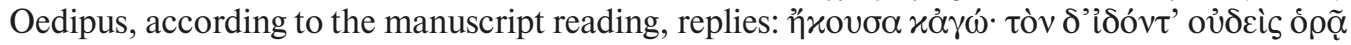
(v. 293). This reading must refer to the witness who is hiding and thereby concealing the truth.

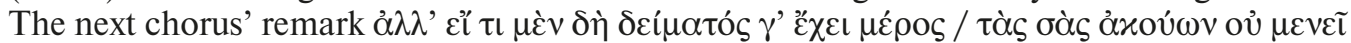

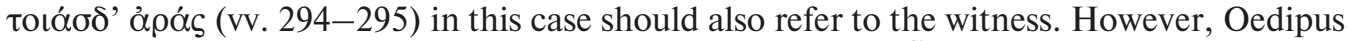

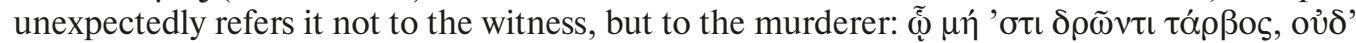

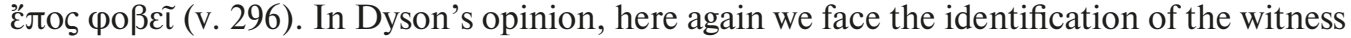
and the murderer - an idea which, as the researcher believes, runs "deep in the king' mind". This interpretation, however, can by no means be correct. First, we have to assume that the character's words do not express his own thoughts, but his subconscious notions, and this is alien to the whole structure of Greek tragedy. Second, Oedipus is convinced that this murder had no bystander. The only person who was present and survived was one of Laius' servants, who, as reported to Oedipus, fled in fear and saw nothing but that there were many murderers (118-123). Therefore we must certainly, together with Finglass (2018, 264, comm. to v. 293),

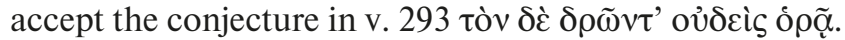

It is impossible to agree with Dyson not only because of his misreading of $v$. 293. The equivalence between the witness and the murderer cannot be a mysterious truth known to the audience but escaping Oedipus for the moment. This equivalence is an obvious fact for everyone: a murderer is always a witness to his crime. Oedipus understands this perfectly well, repeating twice in his edict that the murderer is obliged to denounce himself (vv. 227-228 and 234); what he does not understand is that he himself is the murderer and the witness. Thus, if the ambivalence of this passage is deliberately conceived by the author, its purpose cannot be explained. 
Sophocles then turns to the formula typical for edicts - he promises a reward for law-abiding citizens and threatens punishment for those who disobey ${ }^{15}$. Obviously, the reward is for those who tell about the murderer and the punishment is for those who keep quiet. However, the poet wants to put another, quite different theme into this context - punishing the murderer - and he introduces the murderer into both parts of the formula. It turns out that Oedipus is primarily waiting for information from the murderer himself. If the murderer reveals himself, he will only be removed from the coun-

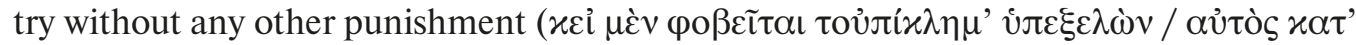

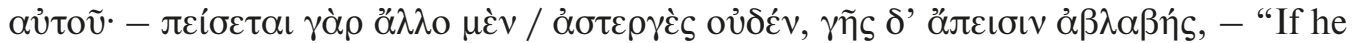
is afraid (to tell) taking out an accusation against himself: he shall suffer nothing else unwelcome, but shall leave the land unharmed", 227-229); if he does not fulfil the commands of Oedipus and continues to hide, he will (of course, after the exposure) be excluded from social life in the city. The murderer becomes the main object of Oedipus' threat. Although the king mentions alongside with him those who are close to him

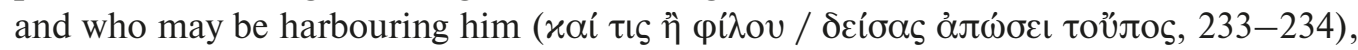
it is the murderer himself that is important to Sophocles. He is named at the end of this

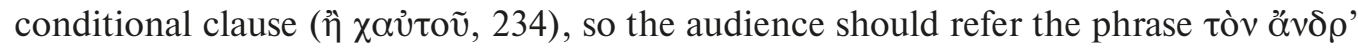

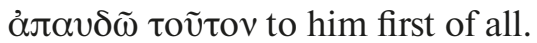

This insertion of the curse upon the murderer into the edict requiring the sharing of information raises other problems beyond the semantic ambiguity of the curse itself. First, it is not entirely clear how the fate of the murderer, if he confesses, will in fact differ from his fate if he remains silent. In both cases he faces exile. Both his leaving the country without any other harm to him in the first case and his excommunication in the second are essentially the same punishment: both mean exile. The contrast is created here purely rhetorically by opposing the word $\alpha \beta \lambda \alpha \beta \eta \dot{s}$ to a long series of phrases ex-

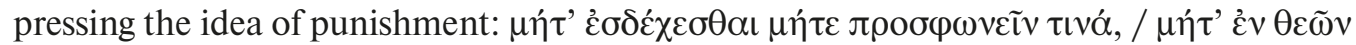

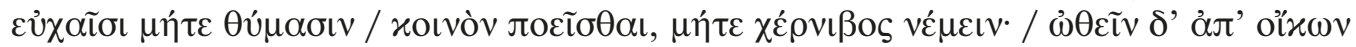

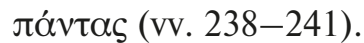

The second problem the author has to solve is how to turn this threat of punishment, which was originally part of the edict, into a curse. This is necessary for Sophocles so that later on in the tragedy, when he refers to this passage, it sound with particular force and really determine the whole fate of the hero: the execution of the punishment to which he has condemned himself must be supervised by the gods. This is why Oedipus immediately turns his edict into a curse. Solemnly concluding the edict with the words $\dot{\varepsilon} \gamma \dot{\omega}$

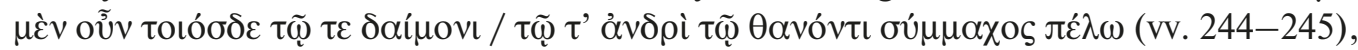

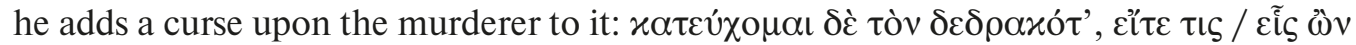

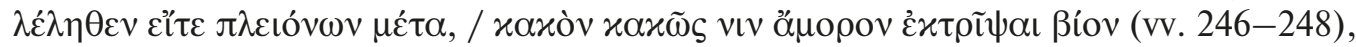
and then he uses the word óox́ to define the very command to exclude the murderer or

${ }^{15}$ We find a similar contrast, for instance, in Creon's edict in Antigone. Creon assigns posthumous honours to Eteocles and posthumous punishment - refusal of burial - to Polynices who fought against his native city. He ends the edict with words stressing the opposite treatment of law-

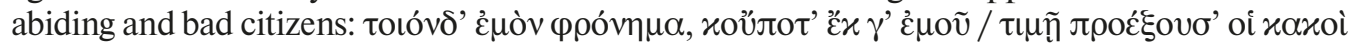

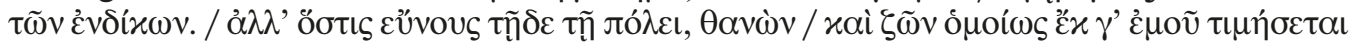
(vv. 207-210). 
his concealer from communication - in a new curse, already addressed to himself, Oe-

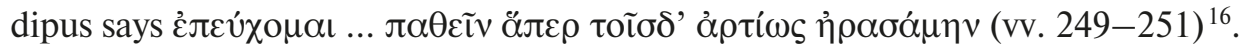

Thus, the semantic ambivalence of vv. 236-243 arises from the fact that this passage, conceived and needed by the author as a curse upon the murderer, is placed in the context of an edict demanding that the Thebans extradite the murderer. This ambivalence also corresponds to the two roles which Oedipus himself unknowingly plays and which Sophocles ironically stresses: Oedipus is both the murderer and the one who knows about the murder; all the curses which he addresses against both the murderer and his concealers apply to himself.

Now it is worth looking at how Sophocles tries to resolve the resulting inconsistency in the passage in question.

As we have already noted, the basis for excluding the culprit from communication in the

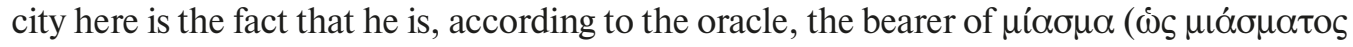

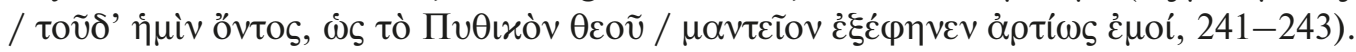
This is true of the murderer, but in no way applies to the possible informant who is hiding the truth. Therefore Oedipus does not address his curse against every informant, but

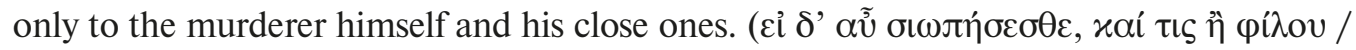

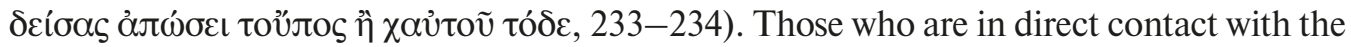
murderer are subject to the same filth as he is; so Oedipus is ready to turn the curse upon

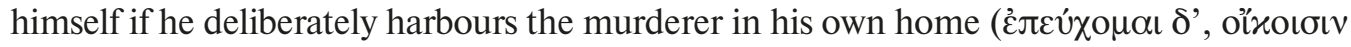

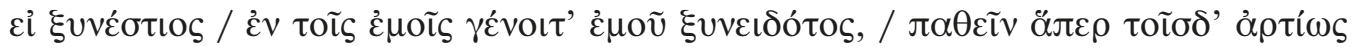
$\eta \jmath \rho \alpha \sigma \alpha ́ \mu \eta v, 249-251)$. An excellent illustration of this notion is a passage from Plato's dialogue Euthyphro, which reveals such a great lexical closeness to the passage from Oedipus Tyrannus that it could be considered an allusion to the text of Sophocles. Euthyphro explains to Socrates that he is right in prosecuting his father, whom he considers responsible for the death of the thes $(\theta \bar{n} s)$, i.e. hired labourer. According to him, if he begins to live in the same house with the murderer, sharing the hearth with him, and, knowing about the murder, does not report on his father, the filth will spread on him:

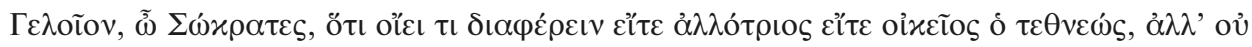

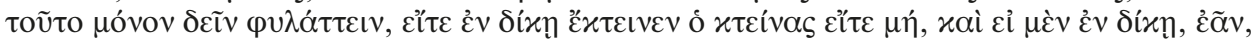

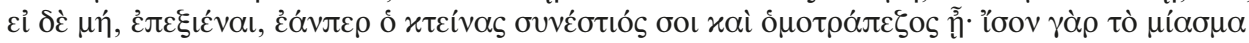

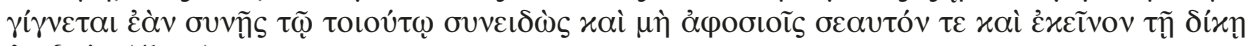

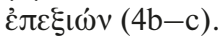

It's ridiculous, Socrates, that you think it makes a difference whether the dead man is from outside or inside the household, but that you don't have to watch out solely for whether the slayer slew lawfully or not, and if it was lawful, let him go and if not, prosecute, even if the slayer

${ }^{16}$ Dyson (1973) has pointed out the genre duality of the monologue which includes both an edict and a curse. But he believes that firstly the command to exclude the culprit from communication only sounds like part of the edict, and only later, in the following parts of the play, it is reinterpreted as a curse. In his view, Oedipus adds the curse in vv. 246-248, referring to the situation in which the murderer remains unidentified: then let the gods make his life miserable. However, Oedipus cannot consider this option. The only aim he seeks is

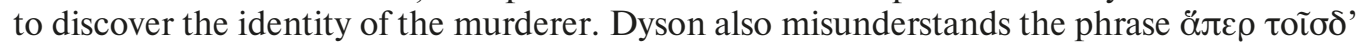

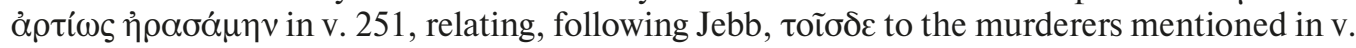

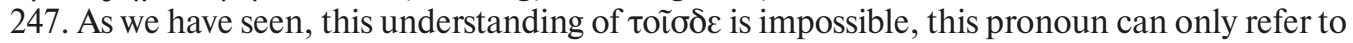
the object of the threat in vv. 236-243; thus already here in v. 251 this threat is called a curse. 
shares your hearth and board. You see the pollution is just as great if you knowingly associate with such a person and don't cleanse both yourself and the other man by taking him to court ${ }^{17}$.

The second way in which Sophocles softens the inconsistency of his text is by a cer-

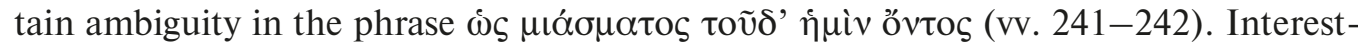
ingly, Tiresias, quoting Oedipus' edict in the next scene, slightly changes the words and the whole construction. He commands the king (vv. 350-353):

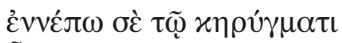

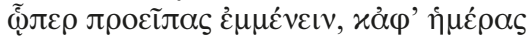

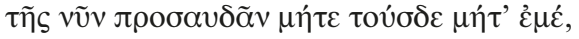

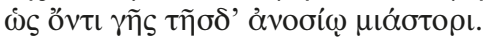
I call on you to abide by the proclamation
you made earlier, and from this day on
address neither these men nor me,
since you are the unholy polluter of this land!

Instead of $\mu i \alpha \sigma \mu \alpha$ he uses the word $\mu$ tóot $\omega \rho$, which unequivocally refers to the murderer and attributes the participle clause to oर́ (the dative case depends on the verb $\dot{\varepsilon} v v \dot{\varepsilon} \pi \omega$ and is used here instead of the genitive, so that the participle clause is not dependent on $\dot{\varepsilon} \mu \varepsilon \dot{)}$. Thus, here the phrase is clearly referring to Oedipus the murderer, who is the source of the filth and therefore is to be punished. In Oedipus' monologue, however, the same participle phrase sounds completely different. The word $\mu$ ía $\sigma \alpha \alpha$ does not describe a person, but a phenomenon ${ }^{18}$; the participial construction does not correspond to tòv ${ }^{\prime \prime} v \delta \rho \alpha$

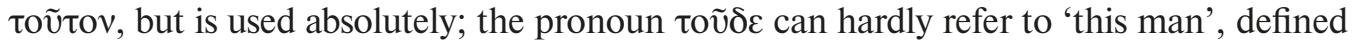
by a completely different demonstrative pronoun. Taken together, these three grammatical facts seem to suggest that Oedipus is not so much referring to the murderer, but to the filth

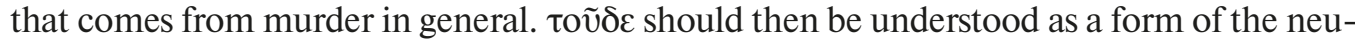

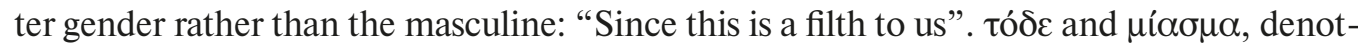
ing not a particular person, but the whole phenomenon of filth in general, can already be referred to anyone on whom the filth spreads, and with this interpretation the phrase would explain why not only the murderer himself, but also his close ones should be expelled.

In this article I have touched upon an important feature of Sophocles' style that needs to be taken into consideration when interpreting his text. Commentators tend to expect logical order and consistency from a text. However, they often achieve this order by distorting the obvious meaning of individual passages. We should admit that the poet may allow inconsistencies, sacrificing clarity in the presentation of facts for other purposes that prove to be more important to him. Sophocles aims more at rhetorical expressiveness and dramatic coherence than at logical clarity and certainty. In this case, he creates a passage of a great emotional power to which the characters will be able to refer again and again throughout the drama and which will ultimately determine Oedipus' fate itself. This passage is placed in a not entirely suitable context, the author tries to smooth over the contradictions that arise between the passage and its context, some inconsistency still remains, but this is not very important to Sophocles, as his artistic tasks are quite different.

${ }^{17}$ Trans. C. Emlyn-Jones and W. Preddy.

${ }^{18}$ In classical Greek literature $\mu$ í $\alpha \sigma \alpha \alpha$ refers only once to a person who is a source of filth in v. 1028 of Choephori, which may be a later interpolation (see Fraenkel 1950, 778 and 815). 


\section{References}

Blaydes, F.H.M. (ed.) 1859: Sophocles, with English Notes. Vol. I. London.

Campbell, L. (ed.) 1879: Sophocles. Vol. I. Oedipus Tyrannus. Oedipus Coloneus. Antigone. $2^{\text {nd }}$ ed. Oxford. Carawan, E. 1999: The edict of Oedipus (Oedipus Tyrannus 223-51). American Journal of Philology 120, $187-222$.

Classen, J. 1861: Ueber die Rede des Königs Oedipus in Sophokles O.R. 216-275 [mit Erwiderung]. Rheinisches Museum für Philologie 16, 489-500.

Dyson, M. 1973: Oracle, edict, and curse in Oedipus Tyrannus. Classical Quarterly 23/2, 202-212.

Finglass, P. (ed.) 2018: Sophocles. Oedipus the King. Cambridge.

Fraenkel, E. (ed.) 1950: Aeschylus. Agamemnon. Vol. I-III. Oxford.

Henry, A.S. 1969: Sophocles, Oedipus Tyrannus 222-43. Classical Review 19/2, 125-126.

Jebb, R. (ed.) 1914: Sophocles: The Plays and Fragments. Pt.I. The Oedipus Tyrannus. $3^{\text {rd }}$ ed. Cambridge. Knox, B.M.W. 1957: Oedipus at Thebes. New Haven.

Knox, B.M.W. (transl.) 1959: Sophocles. Oedipus the King. New York.

Lloyd-Jones, H., Wilson, N.G. 1990: Sophoclea. Studies on the Text of Sophocles. Oxford.

Lloyd-Jones, H. (ed.) 1994: Sophocles. Vol. I. Ajax. Electra. Oedipus Tyrannus. (The Loeb Classical Library, 20). Cambridge (MA)-London.

Ribbeck, O. 1858: Zu Sophokles. Rheinisches Museum für Philologie 13, 129-132.

Ribbeck, O. 1861: Erwiderung an Herrn Direktor Dr. Classen: die Rede des Königs Oedipus in Sophokles O.R. 216 ff. Rheinisches Museum für Philologie 16, 501-510.

Schneidewin, F.W. (Hrsg.) 1856: Sophokles. Bd. II. Oedipus Tyrannus. 3. Auflage besorgt von A. Nauck. Berlin.

Wecklein, N. (ed.) 1880: Sophocles. Oedipus Rex. Leipzig. 